\title{
Assessment of Repayment Performance of Agriculture Credit by Farm Households across Rural Urban Interface of North of Bengaluru
}

\author{
Udaykumar, M.S. and K.B. Umesh \\ Department of Agricultural Economics, UAS, GKVK, Bengaluru, Karnataka, India \\ *Corresponding author: msudaykumar94@gmail.com
}

\begin{abstract}
The study was undertaken in North of Bengaluru to Assess the Repayment performance and factors affecting repayment capacity of agriculture credit by farm households across rural urban interface. The required primary data was collected from randomly selected 50 farmers each under rural, peri-urban and urban transacts. The results revealed that the farmers availed more credit from formal sources compared to informal sources across all transacts. Repayment was more in urban areas $(50.36 \%)$ compared to periurban ( $43.05 \%)$ and rural (34.52\%) areas. The farmers were categorized based on the extent of repayment across rural urban interface and the results indicated that, 42 per cent of rural farmers, 40 per cent of peri urban and 34 per cent of urban farmers fall under the category of 75 to 100 per cent repayment. Low price, crop loss and higher household expenditure occupied the major reasons for indebtedness of farm households in all the three transacts. Multiple regression analysis was carried out to know the factors affecting repayment capacity and regression results showed that Amount borrowed and interest rate were the factors which significantly affected the repayment capacity of farm households.
\end{abstract}

Keywords: Agriculture credit, Repayment performance, Interface, Indebtedness and Interest rate

Indian agriculture scenario for the few decades has seen tremendous changes in terms of production and productivity. The need for food to meet the growing population is increasing day by day. But the percentage of people practicing agriculture has been decreasing over the decades. This can be attributed to many of the causes. In India, the percentage of small and marginal farmers is very high in comparison with the large scale farmers. Around 79 per cent farmers are small and medium where 14 per cent are landless farmers. Large farmers account for only 7 per cent of the total farmers. According to a survey report by the centre for the study of Developing Societies (CSDS), Delhi, around 62 per cent of farmers are ready to quit farming if they get a good job. The survey also found that nearly 72 per cent of farmers like their profession and around 22 per cent of farmers don't like doing farming. There are many reasons which explain the problems of farmers not to continue farming profession. The main reason is profitability and availability of high cost inputs.

Profitability is related with crop output prices whereas the availability of high cost inputs is related with the funds the farmer has. Credit supply is an important determinant of investment in agriculture. Majority of the farmers lack the ability to organise the funds for their farming profession. In this regard, Formal and informal sources of credit play an important role. The formal sources of credit include commercial banks, co-operative banks, RRB's, MFI's and SHG's. Whereas the informal sources of credit comprise of commission agents, money lenders, relatives and friends.

To meet the growing needs of population, agricultural credit is one of the important factor. Agricultural loan is a crucial input in smallholder agriculture. It enables farmers to establish and 
expand their farms as this would increase their income and ability to repay loans. The people tend to under-utilise, default more on loans that are taken from sources which impose lesser punishment in the future. Repayment of loans depends on a number of factors, such as purpose for which loan is taken, education, family expenditure, amount borrowed, gross income, percentage of interest rate, tenure of the loan and source of borrowing.

This study examines the source and purpose of borrowing, consumption and production patterns of households taking loan from different sources to gain insight towards the existence loan system and studies utilisation of loans taken from formal versus informal sector and the subsequent loan repayment behaviour of these households. In this backdrop the present study was carried out with the following objectives:

1. To assess the repayment performance of farmers across rural urban interface of Bengaluru.

2. To identify factors affecting the repayment performance of farmers.

\section{Methodology}

The present study was carried in rural-urban interface of north of Bangalore in Karnataka during 2017. North transect was further divided into three layers namely rural, interface (peri-urban) and urban areas. The distinction of the areas into rural, interface (peri-urban) and urban areas was made based on the survey stratification index developed by considering percentage of built-up area and its linear distance from the city centre. The building of the state legislature, Vidhana Soudha was used as the reference point to measure the distance. Up to about 20 to $25 \mathrm{~km}$ away from the city centre building density was strongly correlated to distance (the closer to the city, the higher the percentage of built-up area). Beyond that, however, the two parameters were negatively correlated. The present study focuses on the Repayment performance and factors affecting the Repayment of agriculture credit by farm households across rural urban interface of north of Bengaluru. The villages were selected randomly across all the three transacts. The purposive multistage random sampling method was adopted for the selection of borrower farmer households. The sample frame consists of 150 farmers representing 50 each from the rural, interface (peri-urban) and urban areas, respectively. Farmers were interviewed using pretested wellstructured schedule by personal interview method.

\section{Nature and source of data}

In order to address the objectives of the study, data was obtained from the selected farmers using a pre-tested well-structured schedule developed for the study through personal interview. The information elicited from the respondent farmers pertained to cropping pattern, land holdings, asset position, family size, educational level, decision making. Further the data on the amount and purpose of credit borrowed from different sources, utilization pattern of borrowed credit, transaction cost involved in borrowing credit, repayment pattern etc was collected. Data pertaining to both short term and term loans were collected from the sample respondents across rural-urban interface of north of Bengaluru. In case of long term loans the farmers who borrowed loan from the year 2013 were considered. The field survey was conducted during January-February, 2017.

\section{Regression analysis}

To analyze the factors affecting the repayment capacity of the farm households across three transacts of North of Bengaluru, multiple linear regression analysis was used, considering amount of credit repaid as dependent variable. Education, family expenditure, amount borrowed, gross income and interest rate were the independent variables.

Grouping variable: Grouping variable is the set of dummy variables that defines the farm household in rural, peri-urban and urban areas.

Predictor variable: Predictor variables are a set of independent variables which help to discriminate the groups.

The empirical model specified is as follows:

$$
\begin{aligned}
Y= & a+b_{1} X_{1}+b_{2} X_{2}+b_{3} X_{3}+b_{4} X_{4}+b_{5} X_{5}+b_{6} D_{1}+ \\
& b_{7} D_{2}+e
\end{aligned}
$$

Where,

Y: Amount repaid (₹)

$X_{1}$ : Education (Years of schooling) 
$X_{2}$ : Family expenditure $(₹)$

$X_{3}$ : Amount borrowed (₹)

$X_{4}$ : Gross income (₹)

$X_{5}$ : Interest rate $(\%)$

$D_{1}$ : Dummy variable as ' 10 ' for urban farm households

$D_{2}$ : Dummy variable as ' 01 ' for peri-urban farm households

And dummy '0 0 ' for rural farm households

$e$ : Error term

$b_{1}, b_{2}, \ldots \ldots . b_{5}$ are the regression co-efficient for the variables $X_{1}, X_{2}, \ldots \ldots X_{5}$ respectively.

$b_{6}$ and $b_{7}$ are the regression coefficients for dummy variables $D_{1}$ and $D_{2^{\prime}}$, respectively.

\section{Chi-square independent test}

This is a most frequently used non-parametric statistical test in social sciences as it can be used for any levels of measurement in general and nominal variable in particular. Chi-square test of independence was used to evaluate group differences when the dependent variable is nominal, dichotomous, ordinal, or grouped interval. The Chi square test of independence allows the researcher to determine whether variables are independent of each other or whether there is a pattern of dependence between them. If there is dependence, the researcher can claim that the two variables have a statistical relationship with each other.

This approach consists of four steps:

1. State the null and alternative hypotheses

2. Formulate an analysis plan

3. Analyze the sample data

4. Interpretation of results

Step 1: Null Hypothesis $\left(\mathrm{H}_{0}\right)$ : Two variables are independent

Alternative hypothesis $\left(\mathrm{H}_{1}\right)$ : Two variables are not independent.

Step 2: This deals with the use of the data to accept or reject the null hypothesis. In this stage researcher also needs to set up the significance level. Often, researchers choose significance levels equal to 0.01 , 0.05 , or 0.10 .

Step 3: Using sample data from the contingency tables, find the degrees of freedom, expected frequency counts, test statistic, and the P-value associated with the test statistic. The formula used to find out the Chi square statistic is as follows:

$$
\chi_{i j}^{2}=\sum \frac{\left(O_{i j}-E_{i j}\right)^{2}}{E_{i j}} \text { Follows } \chi^{2}((r-1) \times(c-1) \mathrm{df})
$$

Where,

$O_{i j}$ is the observed number of cases with respect to $\mathrm{i}^{\text {th }}$ factor in $\mathrm{j}^{\text {th }}$ district,

$E_{i j}$ the expected number of cases with respect to $\mathrm{i}^{\text {th }}$ factor in $\mathrm{j}^{\text {th }}$ district.

$\mathrm{N}$ is the total number of observations, $\mathrm{r}$ is number of rows, $\mathrm{c}$ is number of columns and $\mathrm{df}$ is the degrees of freedom $((r-1) \times(c-1))$

The expected value of the each category can be calculated as follows:

Expected number of $i j^{\text {th }}$ case $=\left\{\left(i^{\text {th }}\right.\right.$ row total $\times j^{\text {th }}$ column total) / grand total\}

This Chi square statistic is obtained by calculating the difference between the observed number of cases and the expected number of cases in each category. This difference is squared and divided by the expected number of cases in that category. These values are then added for all the categories, and the total is referred to as the Chi squared value. Since the test statistic is a Chi-square, use the Chi-Square distribution calculator to assess the probability associated with the test statistic using the degrees of freedom computed above.

Step 4: Reject the null hypothesis if the probability of test statistic is less than or equal to alpha (0.05) In the present study, this test was employed to know the significance difference between reasons opined by farm households for the indebtedness across rural urban interface

\section{RESULTS AND DISCUSSION}

\section{Total credit borrowed by farmers from different sources}

Total credit borrowed from different sources indicated that the quantum of credit borrowed was more in urban ( $₹ 5,16,000)$ followed by peri-urban $(₹ 3,77,000)$ and rural $(₹ 2,97,000)$ area (Table 1). It 
Table 1: Total credit borrowed from different sources across rural-urban interface

\begin{tabular}{cccc}
\hline Study area & Formal sources (₹) & Informal sources (₹) & Total (₹) \\
Rural & $1,78,000(59.93)$ & $1,19,000(40.06)$ & $2,97,000(100)$ \\
Peri-urban & $2,86,000(75.86)$ & $91,000(24.13)$ & $3,77,000(100)$ \\
Urban & $4,34,000(84.10)$ & $82,000(15.89)$ & $5,16,000(100)$ \\
\hline
\end{tabular}

Note: Figures in parentheses indicate per cent to total.

was evident from the results that the total amount borrowed from formal sources was ₹ $1,78,000$ in rural, ₹ $2,86,000$ in peri-urban and ₹ 4,34,000 in urban areas which constituted 59.53, 75.86 and 84.10 per cent to the total credit borrowed, respectively. Whereas, 40.06 per cent of amount borrowed in rural, 24.13 per cent of amount borrowed in perurban and 15.89 per cent of the amount borrowed in urban areas was met from the informal sources. More amount is borrowed from formal sources across all the transacts. This can be attributed to better accessibility for banking services and the reasonable rate of interest and formal sources also gives security to the farmers than the informal sources It is interesting to notice that farmers in rural areas borrowed more from informal sources compared to farmers in urban and peri-urban area because of timely availability and easy accessibility. As we move from rural to urban areas the quantum of credit availed from formal sources was increasing whereas the quantum of credit availed from informal sources decreased. The credit needs of farmers have been growing due to increase in the commercialization of agriculture across all the transacts (Task Force on Rural Credit, 2010).

\section{Distribution of sample farmers based on extent of repayment across rural-urban interface}

The farmers were categorized based on the extent of repayment across rural urban interface and the results indicated that, 42 per cent of rural farmers, 40 per cent of peri urban and 34 per cent of urban farmers fall under the category of 75 to 100 per cent repayment because after availing loan the farmers had taken up the cultivation of vegetables and fruit crops, livestock rearing in rural area whereas fruit crops, commercial lawn cultivation and poultry in peri-urban area which helps in getting higher income to the farmers because of assured market. This can also be supplemented with the fact that there was cent per cent utilization of credit for cultivating high value crops and also for digging bore well. Urbanization paved an important role in terms of established and assured market which was also a major reason for the higher repayment in peri-urban and urban areas. In rural area 26 per cent of the borrowers fall under 0 to 25 per cent category followed by 25 to 50 per cent (18\%). In rural area the repayment was less because of crop loss and low price for their produce which resulted in decreasing the farm income compared to periurban and urban area. Low price for agriculture produce leads to decrease in farm income which intern decreased the repayment capacity (Fig. 1).

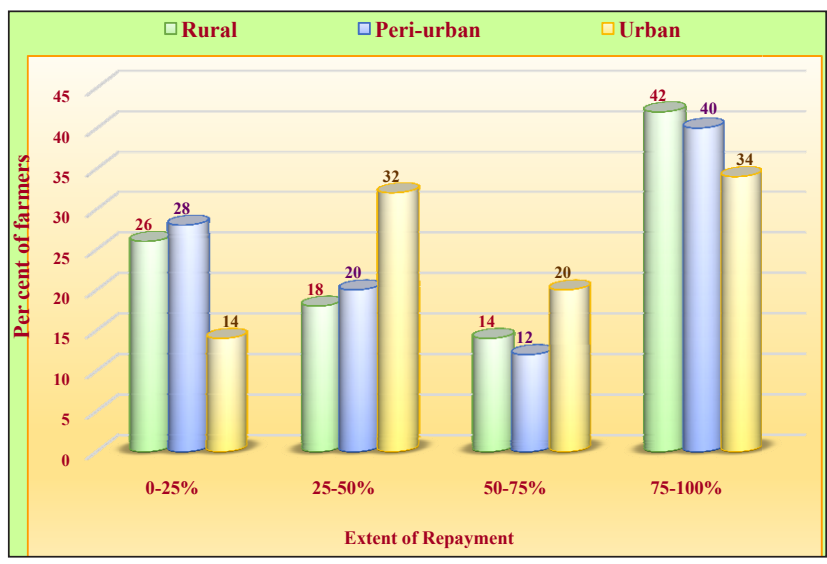

Fig. 1: Distribution of sample farmers based on extent of repayment across rural urban interface

\section{Source wise repayment of credit by farm households}

Source wise repayment of credit by farm households across rural urban interface is given in Table 2 . Results showed that repayment was more in case of formal sources when compared to informal sources. Among formal sources, the repayment performance was more in co-operative banks in rural $(63.60 \%)$, peri-urban $(62.38 \%)$ and urban $(66.88 \%)$ areas because farmers had to clear old debts/loan in order to take loan in the coming years and also interest rate was less in co-operative banks, proper utilization of credit by farmers, which made 
Table 2: Source wise repayment of credit by farm households across rural urban interface (per cent of loan repaid)

\begin{tabular}{cccccccccc}
\hline & \multicolumn{4}{c}{ Formal sources } & \multicolumn{5}{c}{ Informal sources } \\
\cline { 2 - 10 } Study area & $\begin{array}{c}\text { Commercial } \\
\text { Bank }\end{array}$ & $\begin{array}{c}\text { Co-operative } \\
\text { bank }\end{array}$ & RRB & MFIs & SHGs & $\begin{array}{c}\text { Commission } \\
\text { agents }\end{array}$ & Money lender & Relatives & Friends \\
\hline Rural & 47.10 & 63.60 & 56.7 & 33.30 & 100.00 & 0.00 & 37.00 & 16.70 & 0.00 \\
Peri-urban & 42.87 & 62.38 & 50.67 & 33.33 & 100.00 & 40.00 & 23.03 & 26.39 & 20.00 \\
Urban & 46.52 & 66.88 & 66.67 & 82.50 & 100.00 & 14.67 & 40.67 & 11.11 & 50.00 \\
\hline
\end{tabular}

Note: RRB -Regional Rural Banks, MFIs- Micro finance institutions, SHGs- Selp Help Groups.

Table 3: Reasons opined by farm households for the indebtedness across rural urban interface ( $\mathrm{n}=50$ ) (in per cent)

\begin{tabular}{cccccc}
\hline S1. No. & Reasons & Rural & Peri-urban & Urban & $\chi^{2}$ value \\
\hline 1 & Low price of farm produce & 78 & 68 & 70 & $0.77(0.679)$ \\
2 & Crop loss & 74 & 70 & 74 & $0.14(0.929)$ \\
3 & Higher household expenditure & 72 & 64 & 68 & $0.47(0.790)$ \\
4 & Increased cost of cultivation & 68 & 61 & 66 & $0.4(0.818)$ \\
5 & Expectation of loan waiver & 58 & 42 & 50 & $2.56(0.278)$ \\
6 & High rate of interest & 42 & 58 & 34 & $6.68(0.035)$ \\
7 & Low profit margin to farmers & 36 & 48 & 40 & $1.80(0.40)$ \\
8 & Poverty & 30 & 12 & 32 & $9.83(0.007)$ \\
9 & Diversion of fund & 28 & 36 & 36 & $1.28(0.52)$ \\
10 & Others (death/health problems) & 12 & 16 & 14 & $0.57(0.751)$ \\
\hline
\end{tabular}

Note: Figures in the parenthesis is indicates the ' $p$ ' value.

the farmers to repay the loan in a specified period. The lower repayment of loan was noticed for the credit borrowed from commercial banks across all the transacts and is because the borrowers are very much affected by psychological feeling of waiving off loan by the government (Singh and Sah, 2004), high rate of interest. Across all transacts cent per cent repayment was observed for the loan borrowed from Self-Help Groups (SHGs). Among informal sources, 37, 23 and 41 per cent of the repayment was made for the loan borrowed from money lenders in rural, peri-urban and urban area, respectively. Repayment of loan borrowed from money lenders was high in rural and urban areas, whereas in periurban area repayment per cent was more for the loan borrowed from commission agents (40.00\%).

\section{Reasons for the indebtedness}

The different reasons opined by farmers for the indebtedness were collected and results are presented in Table 3. The results indicated that, in the rural area low price for the agricultural produce $(78 \%)$ was the major reason for indebtedness followed by crop loss (74\%) and higher household expenditure (72\%). In peri-urban area 70, 68 and 64 per cent of the farmers opined that, crop loss, low price and higher household expenditure were the major reasons for indebtedness, respectively. Similar reasons were also opined by urban farmers. It is interesting to note that low price, crop loss and higher household expenditure occupied the major reasons in all the three transacts. Because of crop loss and low price of the produce the farmers income was reduced there by borrowers could not meet even the family expenditure from the obtained income which resulted in indebtedness of farmers. Higher household expenditure, increased cost of cultivation, expectation of loan waiver were also the reasons which results in indebtedness of farmers. The results of Dhananjaya, 2015 aptly supported the findings of the study. The significant difference in the opinion of indebted farmers across three transacts was found in the reasons such as poverty, crop loss and high rate of interest. These findings are in line with the results of Pratibha and Salawade (2008). More than 60 per cent of the farmers in all the three transacts opined that increased cost of cultivation was also a reason for indebtedness. 
Table 4: Factors affecting the repayment capacity of farm households across rural-urban interface

\begin{tabular}{clccc}
\hline S1. No. & Variables & Parameters & Coefficients & t value \\
\hline 1 & Intercept & $\mathrm{a}$ & $33180.75(42987.7)$ & 0.77 \\
2 & Education $\left(\mathrm{X}_{1}\right)$ & $\mathrm{b}_{1}$ & $2965.58(3085.51)$ & 0.96 \\
3 & Family expenditure in $₹\left(\mathrm{X}_{2}\right)$ & $\mathrm{b}_{2}$ & $0.5583(2.969)$ & 0.19 \\
4 & Amount borrowed in $₹\left(\mathrm{X}_{3}\right)$ & $\mathrm{b}_{3}$ & $0.3281(0.021)$ & $15.76^{* *}$ \\
5 & Gross income in ₹ $\left(\mathrm{X}_{4}\right)$ & $\mathrm{b}_{4}$ & $0.0099(0.043)$ & 0.23 \\
6 & Interest rate in per cent $\left(\mathrm{X}_{5}\right)$ & $\mathrm{b}_{5}$ & $-3794.72(1898.20)$ & $-1.99^{*}$ \\
7 & $\mathrm{D}_{1}$ (Urban) & $\mathrm{b}_{6}$ & $105346.70(40867.28)$ & $2.57^{* *}$ \\
8 & $\mathrm{D}_{2}$ (Peri-urban) & $\mathrm{b}_{7}$ & $23010.75(36833.46)$ & 0.62 \\
\hline 9 & Co-efficient of multiple determination $\left(\mathrm{R}^{2}\right)$ & \multicolumn{2}{c}{70.02} & \\
10 & Adjusted Co-efficient of multiple determination $\left({ }^{2}\right)$ & & 68.01 & $1.03 \mathrm{E}^{28 * *}$ \\
\hline
\end{tabular}

Note: 1 . Figures in parentheses indicates standard error; $2 .{ }^{* *}$ - Significant at 1 per cent; $3 .{ }^{*}-$ Significant at 5 per cent.

\section{Factors affecting the repayment capacity of farm households across rural-urban interface}

Multiple linear regression analysis was carried out to find out the factors affecting the repayment capacity of farmer borrower and the results are presented in Table 4 . The ' $\mathrm{F}$ ' value of the regression was 40.42 and was significant at one per cent indicating good fit of the model. The co-efficient of multiple determination $\left(\mathrm{R}^{2}\right)$ was 0.70 indicating that the variables included in the regression model explained about 70 per cent of the variation in repayment capacity. The threshold loan amount repaid was $₹ 33180.75$ per farm which is the contribution of other factors which are not included in the regression analysis.

The regression coefficient for amount borrowed was 0.3281 and was statistically significant at one per cent indicating that, the marginal propensity to repay on the amount borrowed was ₹ 0.3281 . Regression coefficient for interest rate was ₹ -3794.72 and is statistically significant at five per cent. As the interest rate increases by one per cent, the loan repayment decreases by ₹ 3794.72.

To find the extent of repayment across urban, periurban and rural farm households, two dummy variables were used viz., $\mathrm{D}_{1}$ for urban farmers, $\mathrm{D}_{2}$ for peri-urban farmers. The intercept indicates the threshold loan amount repaid, which was ₹ $33,180.75$ per farm. Due to urbanization, the threshold loan amount repaid per farm is shifted by $₹ 1,05,346.70$ as given by the coefficient of the dummy variable $\left(D_{1}\right.$ was significant at one per cent) used for farmers in the urban areas. Hence, the threshold loan amount repaid per farm in urban area was $=₹ 33,180.75+₹ 1,05,346.70=₹ 1$, $38,527.45$ per farm. In peri-urban areas, threshold loan amount repaid per farm is shifted by Rs. 23,010.75 per farm indicating that the threshold loan amount repaid per farm in peri-urban area was ₹ 56,191.50 (₹ 33,180.75 + ₹ 23,010.75). The results clearly indicated that, threshold loan amount repaid was more in urban farmers followed by peri-urban and rural farmers. This was due to the fact that the average land holding size was more in urban area and also the gross income realized was also more in urban area compared to peri-urban and rural farmers. The majority of urban farmers were involved in cultivating high value horticulture crops which yield higher income compare to food crops. The loan amount borrowed had positive impact on the repayment amount. The results of Nwosu et al. (2014) are in accordance of this study. Whereas, interest rate had a significant $(p<0.05)$ negative influence on the amount repaid (Ojiako et al. 2015). The factors such as family expenditure, education and gross income affected the amount repaid by farm households positively but found non-significant.

\section{CONCLUSION}

Agricultural credit is important valuable tool to assist the economic development of a country by means of empowering the farming community. The development of agriculture sector is more dependent on banking sector because, 80 per 
cent of farmers are small and marginal, who are unable to save and invest due to their low levels of income. Through the above mentioned facts and figures it can be concluded that high interest rate on agricultural loans, low price of farm produce, increase cost of cultivation, diversion of funds etc. caused delay in repayments of agricultural credit. To enhance the repayment performance of farmers there is a need to link credit with marketing in all the lending activities as it is being done in dairy sector. Financial institutions should develop thorough monitoring and tracking system by regular visits of the field officers to the farm fields and also in order to avoid the diversion of agricultural credit for other purposes bank may adopt alternate method of providing primary/seasonal inputs.

\section{ACKNOWLEDGEMENTS}

I wish to thank farmers for sparing their valuable time in giving the information and Department of Biotechnology, Government of India for providing financial assistance under Indo German Collaborative Project, grant number BT/IN/GERMAN/DFG/14/ BVCR/2016 dated 16/11/2016 for the duration 201617 to 2018-19.

\section{REFERENCES}

Anonymous, 2010, Report of task force on credit related issues of farmers, pp. 1-83.

Dhananjaya Swamy, P. S., 2015, Flow of institutional credit to agriculture and allied sectors in Karnataka-an economic analysis. Ph.D. Thesis (Unpub.). Univ. Agric. Sci., Dharwad, Karnataka.

Nwosu, F.O., Okorji, E.C., Nweze, N.J., Orebiyi, J.S., Nwachukwu, M.O. and Ibekwe, U.C. 2014, Loan accessibility and repayment performance of livestock farmers under the agricultural credit guarantee scheme fund in southeast, Nigeria. Developing Country Studies, 4(6): 63-69.

Ojiako, I.A., Okechukwu, R.U. and Olaitan, T. 2015. Econometric analysis of loan repayment competence of smallholder cassava farmers in Yewa area, Ogun State, Nigeria. J. Food, Agric. and Envi., 13(3/4): 158-167.

Pratibha Desai, B. and Salawade, S.N. 2008. Rural indebtedness: With special reference to sugarcane growers. J. Global Economy, 4(1): 67-77.

Singh, R.P. and Sah, A.K. 2004, Repayment performance of borrowers with respect to agricultural loan of Ranchi Kshetriya Garmin Bank: A micro analysis. Indian J. Agric. Econ., 60(3): 396. 
